\title{
Notes o Some Customs of the Lower Congo People
}

\section{The Rev. John H. Weeks}

To cite this article: The Rev. John H. Weeks (1909) Notes o Some Customs of the Lower Congo

People, Folklore, 20:4, 457-480, DOI: 10.1080/0015587X.1909.9719901

To link to this article: http://dx.doi.org/10.1080/0015587X.1909.9719901

\section{曲 Published online: 14 Feb 2012.}

Submit your article to this journal $\pi$

LII Article views: 1

Q View related articles $₫$ 


\section{NOTES ON SOME CUSTOMS OF THE LOWER CONGO PEOPLE.}

BY THE REV. JOHN H. WHEKS, 27 VHARS BAPTIST MISSIONARY ON THE CONGO.

(Continued from p. 3r..)

GAMES.

TIERE are not many games known to the natives. Hockey is played all over the Lower Congo, and in some parts of the Upper Congo. They are intensely fond of the game. No matter how long their journey, or heavy their loads, the lads, a few minutes after they arrive at a resting place, look round for a suitable piece of ground, and, if they can find it, will start a game of hockey. At Wathen Station, where they have a fine open space for their playground, they play hockey at every available opportunity. They put a great amount of energy into the game. On moonlight nights they play "mbele" (described below). This is played by both sexes joining together, and to the beat of their drums and singing. The game led to so much adultery and its attendant "palavers," that, when the Christian Church was formed here, the native members desired that there should be rules to the effect:-(r) That no members of the Church should play mixed "mbele," i.e. the males should play by themselves, and the females by themselves in another part of the town; and (2) that, as the drums badly excited them, the game should be 


\section{$45^{8}$ Customs of the Lower Congo People.}

played without drums. The observation of these rules has led to greater morality among those who observe them, and they are very numerous; any church member breaking them is disciplined.

The small children have their make-belief games. For example, a root of cassava is tied on the back to represent a baby. It has been my experience that it is useless to give them dolls. They do not understand them and are afraid of them, and in a short time the dolls are found on the market places for sale as charms and fetishes. Small boys with sticks will march as soldiers and get up mimic fights, and with old provision tins start a band which you are glad to send into the next district. With bits of sticks, reeds, and grass they make imitation houses with mud walls. Bits of broken saucepan, old tins, and odds and ends from their parents' houses furnish them with the necessary articles for their "pretend" game of house-keeping, receiving visits from each other, and inviting one another to their "makebelief" feasts. It is a toyless land, a land where children are not catered for, but notwithstanding that the youngsters, by their boisterous laughing and loud shouting, seem to get a great amount of joy out of life. The following are the principal games I have noticed:-

I. Game played with "biti" and needle. The players divide into two sides, which we will call $A$ and $B$. All of them have a musical instrument called the "biti," which is a kind of "marimba" (reed instrument). The playing side $A$ sends out one of its men, and in his absence hides a needle, which he has to find guided by the side 13 playing an agreed-upon note simultaneously. The side B decides what the guiding note shall be. On the return of the needle-seeker, the side $B$ begins to play the "biti." When the seeker draws near the needle the guiding note is played, and, as he recedes from it, it is left out. The seeker has not only to find the needle, but also to name the guiding note. If he finds the needle it counts as one 
game to his side, and he or another on the side A goes out again. Should he not find it, then it counts as a game to the other side, and one lad on that side goes out. Of course the "biti" players try to hide the guiding note by playing rapidly, and covering it with variations on the other reeds, A quick ear to catch the repetition and absence of the guiding note is necessary for this game.

2. The following game is played with the beautiful round black seeds of the "Canna" plant, which grows wild in most places on the Congo. The seeds are about the size of buckshot. The players are divided into two sides, $A$ and $B$, and form a circle as they sit on the ground. If the side A plays first, a thrower takes about 25 to 30 seeds in each hand, and throws them out from his hands alternately, counting one, two, three, and so on up to ten, and the rest he throws helter skelter over the cleared space in front of him, yet in such a way as not to disarrange too much the positions of the first 10 seeds he threw, but he tries to do it as carefully carelessly as he can. Before beginning to throw the seeds, the side $A$ has agreed that the seed 5 is the playing seed, and so, the seeds having been thrown, one lad on the side A withdraws a little from the circle out of sight and hearing. Then, if the side B has spotted the playing seed 5 , they pick it up, and say, "That is the seed and its number is 5." It counts as one game to them. If, however, they have not spotted the seed, or pick up the wrong one, then a lad on the side $A$ touches the right one, and the lad who has left his side is called back and picks up the seed that has been touched by the player on his side. That counts as one game to the side A. Any touching or picking up of the wrong seed is counted as a game to the other side. Supposing the side $A$ says that the seed 5 is not the playing seed, then the side $B$ removes that seed, and the lad is recalled and, of course, he finds the seed 5 is gone, and, should he try to help the cheating by picking up another 


\section{Customs of the Lozer Congo People.}

seed, he must declare its number, and the cheating is revealed. To find out the right seed and number, the opponents have to watch the throwing for any hesitation at a particular number, or to see if a seed is purposely thrown to one side; they have to listen for any emphasis on a particular number, and also watch the eyes of their opponents to see if they are all looking towards one particular seed. Again, the lad who leaves must carry away with him a clear plan of how the seeds lay, so that he may be sure of picking up the right seed, as any blunder made counts as a game to the other side.

3. "Mbele" is a game played both on the Upper and Lower Congo. In some places it is played by the movements of the hands and arms, in other places the favourite mode is by moving the feet and legs, and in other places by the quick movements of the knees. Again, one will find two of these modes, if not the whole three, practised at different times in one and the same place. On the Lower Congo, however, the hands are most commonly used, at Monsembe on the Upper Congo the legs, and at Bolobo, also on the Upper Congo, the knees, but the principle is the same. In some places two lines are formed, one playing against the other, but on the Lower Cong ${ }^{\circ}$ the game is played as follows:-The players form a line, and the first lad in the line is called "king." The "king" faces the first player on the line, (i.e. the one who stood next to him), throws out both his hands, draws them back to his breast, waves them in front of himself parallel with his breast, and, after making several feints, shoots out one hand. If the one standing in front of him is able to meet the "thrust" three times by throwing out the corresponding hand, the "king" has to take his place at the bottom of the line. If, however, none in the line is able to meet the "thrust," after three tries, then the last lad in the line is called a "slave" and stands out of the game. The "king" will go up and down the line sometimes until 


\section{Customs of the Lower Congo People. $46 \mathrm{I}$}

all the players are "slaves." Should the "king" be "out" in going down the line, then, when all become "slaves" to another, he has the chance of winning them back from the last one left "in," by playing him. The movements are very rapid, aud cause a great amount of amusement, and help to train their eyes, and make supple the limbs.

4. Hoop. Sides are taken which have to stand from 20 to 25 yards apart. Each player has a string 2 or 3 yards long weighted at each end. A hoop is trundled from the side $A$ towards the side $B$, and, as it approaches, the weighted strings are thrown at it, so as to entangle it. The boy whose string entangles the hoop, picks up one end of his string, and swings the hoop round his head as he walks with it towards the side A. Should he deposit it there without the hoop dropping from the string, it counts as one game to the side $B$. If the hoop is either not entangled, or drops while being whirled, the game counts to the side $A$. If two or more strings entangle the hoop, then the boys owning the strings must carry the hoop back between them. The hoop must not be touched by the side $B$ unless no string entangles it, when it is thrown back to the side $A$ and counts as a game to them. Sometimes the winner is challenged to whirl the hoop near the ground and to jump over it while whirling without its touching the ground. After a set of 20 games the other side trundles the hoop. Did they learn this game from seeing the Portuguese, in the old times, throw their "bolas" to entangle the legs of their animals? A variation may be made in the above game by throwing the hoop in the air.

5. A person sits in the centre surrounded by a circle of players, or sometimes a single player sits in front of a line of players having their feet extended towards him. The single player takes a ball on his knees, and by jerking a leg he throws the ball to the line of players in front of him. The one who fails to keep the ball from dropping to 
462 Customs of the Lower Congo People.

the ground has to take the place of the thrower and dance for the entertainment of the others, and then sit down and try to catch some one else by jerking the ball.

6. "Nkiendi" is a game in which all the players but one run about on all fours, but face uppermost, one person alone being allowed to stand up; he is called the "antelope," and the others are called "hunters." They scuttle about in this ridiculous attitude, and each tries to touch or kick the "antelope" with his foot. A large court has been marked out on the ground, and the "antelope" is not allowed to go outside it. The "hunters" try to hem him up in a corner. If the antelope, to avoid being touched, runs out of the court, every one gets on their feet and chases him, and he who first pretends to cut him up with a knife becomes the "antelope" next time. A general meléc ensues, every one pretending to cut him up, amid shouts of "leg for me," "head for me," and "some flesh for me." Sometimes a rule is made that there shall be no chasing beyond the court, and, if the "antelope" runs from the court, the first "hunter" who cries out "It has run out" becomes the "antelope." (Cf. Bentley, Dictionary" and Grammar of the Kongo Language, p. 494.)

Among other games played are: "touch"; a kind of "hunt the slipper," boys sitting in a ring and passing a palm-nut behind them from one to the other, and the lad in the centre having to catch the boy who really has the nut, and then changing places with him; odds and evens at cards; counters made of old pieces of crockery, white on one side and with a part of the original pattern on the other side, are used like dice, and with this game and cards a great amount of gambling takes place; hopping the longest; throwing in the hole; etc. With their fingers and toes and three or four yards of string they make a large variety of cat's cradles, each one having its own name. 


\section{Customs of the Lozuer Congo People. 463}

\section{DANCES.}

To a Congo native there is something electrical, moving, exhilarating about the beat of a native drum. Directly he hears it his body begins to twitch and sway to and fro in rhythm to the beat, a smile spreads over his face, weariness is forgotten, dull care is thrown to the winds, and he is soon shuffling round the circle, or has taken his place in the line, clapping his hands and singing a chorus in admirable time.

Every kind of event gives occasion for a dance. If a serious sickness excites general sympathy and desire to help, a dance is arranged, and the whole night is spent in gyrating round a drum. If there is to be a fight, a dance is started, and through the night they circle about a fetish image, calling upon it to work confusion and death among their enemies. If a victory is to be commemorated, the drums beat a joyful, defiant note, and, firing their guns and waving their knives, amid much laughter and covered with perspiration, they shake their bodies and try to excel each other in their antics. A birth, a death, a restoration from illness, a return from a long journey, and the start for a journey, all demand a dance; and, if there is no such ostensible reason, then they will find one, or dance for the mere love of it. Both married and single women participate in all the dances, except the hunting dance, which is only for men. As will be noted, some of the dances take place at night, and continue until the dawn appears; such dances are in connection with their fetishes, and are danced through the night because the spirits are then abroad against whom they are invoking the power of their fetishes. Other dances are for the evening moonlight, or for the glare of the bonfire, and others, such as the dance after a victory, are only performed during the daylight. All kinds of drums are used,-long and short, ovoid,
oblong, and round. They are either beaten by the hand 


\section{Customs of the Lower Congo People.}

or with a stick, or vibrated with friction. The drum and the beat indicate the kind of dance, as certain drums only are used for certain dances. To European eyes there is not much "poetry of movement" about their dances. There is a raising of the shoulders, a wriggling of the buttocks, a quivering of the posterior, and a throwing up of the legs, with occasional jumps in the air. The movements are sometimes suggestive and obscene, and in one or two dances the opposite sexes embrace, such dances leading to much immorality.

In their dances there are two formations-the circle and lines. In the former they dance round a drum or a fetish image, or both, one or both being placed in the centre of an open space, and men and women join, without order, in clapping their hands, chanting a chorus, and shuffling one behind the other in a circle; in the latter, two lines are formed,-one of men and the other of an equal number of women. The drum is placed at one end of the line, and all begin to clap, chant, shuffe, and wriggle together. A man then advances, dancing, and a woman from the opposite line advances a few paces, and they dance thus a few moments with a space of two to three yards between them, next they retire, and others take their places, and so on, right down the lines; and then they start again and again.

The following are the names and particulars of various dances. In their chants and choruses so many obsolete words are used that the singers themselves do not know what they mean. They seem to have become mere nonsense phrases that fit the rhythm of the beaten drums.

1. Ekinu. This is a fetish dance, and is continued all night, with much palm-wine drinking. It is a circulat dance, and is performed while the "ngang' a lembe" is making medicine for his patient. The fetish is put in the middle of the circle, and the drum behind the patient. The drum is beaten and rattle shaken, and the people 


\section{Customs of the Lower Congo People. 465}

sing a chorus, "Luvemba luampene o moyo o njela Ngoyo," (literally, naked chalk life on the Ngoyo road). Ngoyo is Kabinda, a country north of Congo, and this ceremony and song are said to have been introduced by a Kabinda nganga, who visited this country. The original sense has been lost. If the Mbambi fetish is used, the chorus sung is, "Ngwa e tembwa 'yi, mbambi yuna" (Oh! these storms, that Mbambi fetish). Again the real meaning is lost, and perhaps some of the original words. As the drum is beaten the nganga drives the fetish power into the sick man, and he, being excited by the drumming, rattling, and singing, jumps on the nearest roof, tears handfuls of grass from it, and leaps off and on the roof like a madman. The nganga puts some juice from the "lemba-lemba" leaves and "nsangalavwa" stems on him to soothe and quieten him. He is then supposed to get better. Having had the fetish power put into him, he himself becomes a nganga, and can practise curing others. When a woman comes under the sway of the fetish power she becomes a female nganga, and is called "nengudi."

This "ekinu" dance is performed at the christening ceremony of a spirit child when the "ngang' a nkisi" is called to remove the evil that may be in the child because of its spirit nature. (See "Water Spirits" below.)

There is also a similar dance and ceremony observed over girls with the names of Nkenge and Nsona, and boys with the names of Lubaki and Mbaki, but the reason for the observance of the ceremony in their case is lost. "Nkenge" and "Nsona" are names of market days, and are given to such girls as are born on either of those days. There must be something special about some of the four days of their week, as in some districts they never bury on either Nkenge or Konzo, but only on Nsona and Nkandu. There are, therefore, children born on certain days who require an all-night dance to free 


\section{Customs of the Lower Congo People.}

them from some evil, and other days upon which the dead may not be buried. Have they lucky and unlucky days?

2. Nloko (removing witch power, from "loka," to bewitch, and its reverse "lokola.") This is a circular dance, and is performed for the following reasons:-(a) If a person has been ill for a very long time, and one after another of the ngangas has failed to cure him, the various ngangas bring their fetish images, charms, and drums, all of which are placed in the centre, and the adult men and women dance round them, and after a time form a procession and parade through the streets of the village. These circular dances and parades are continued all night, and it is supposed that the sum total of all the strength of the fetishes present will destroy the witch who is retarding the recovery of the patient. The evil spirits being about at night, that is assumed to be the best time to deal with them. (b) As a war dance, i.e. before a fight begins, and as it proceeds. For details, see p. 36 supra.

3. Nsundi is danced in the day-time, or in the evening moonlight, by both men and women and boys and girls. A very high drum is used, and the men wear skins, of cloths in imitation of skins, and these are thrown about by the knees and thighs of the wearers as they jump about in the dance. The formation is in two lines opposite each other.

4. Etutu. This is the name of a very old dance, and in it the "dingwiti" drum (a friction drum now reserved for the "ngang' a ngombo"), some small drums, and reed pipes or whistles formed the band. The dancers had long sticks in their hands, with bells, or anything that jingled, affixed to the top end. It was danced by a line of men and a line of women. The shoulders were worked as well as the legs. Dingwiti is a drum used now in fetish palavers only by the "ngang' a ngombo." (See vol. xix., p. 416.) Through the skin drum-head is a strong cord knotted at the end to keep it from being 
Customs of the Lower Congo People. 467

pulled through, and at the other end is a smooth stick. The fingers are wetted, and the stick drawn through them, and the drum-head vibrates and gives out a particular note.

5. Ntuta, also called kinkubula and nkombo. This is the same as the old "Etutu" dance, but a large drum with a big hole at the bottom, to make it sound well, is used instead of the friction drum.

6. Sala. A medium drum is used, and the formation is in two lines, one of each sex. This dance is characterised by rapid shaking of the whole body. They make up songs about one another, and the dance often ends in a general melée. In this dance the following exhibition of pride often takes place:-During the dance the chief or important man arrives, and someone not belonging to his family or town goes to the drum, and by beating carries on such a conversation as the following, asking questions and replying to them himself :- "Welcome to you, chief $A$. Are you quite well?" "I am quite well," replies the drummer. "Have you come a long way?" "No, only from my town." "Are you very rich?" "Yes, I have plenty of wives, slaves, pigs, goats, cloth, and money. I am so rich that I don't know how rich I really am. I don't know what to do with my money. It fills my bags, boxes, and houses." "Have you much money with you ?" "Yes, my bag and pockets are full." "Give me some of it, as you are so rich." The foollsh chief, in the vanity and pride of the moment, and to win the admiration of those present, will hand over a sum equal to ten or ffteen shillings, or more, a large amount for these people. Then one of the men with chief A will go to the drum and carry on a similar conversation about the chief of the town, or some other chief present (but not his own chief), and draw money out of them. If the largesse is mean and disappoints the drummer, tap, tap will go the drum and a song on stinginess will be beaten, and words will be bandied about from side to 


\section{Customs of the Lower Congo People.}

side. What started as an innocent dance will end in a general row, and bad blood will be made for many a day. But, if the gift is generous, fulsome praise and flattery will be beaten on the drum, and everybody will be pleased.

Some time ago a band of players and dancers went from Vianga to Matadi to entertain the chief Dimbu and his folk. The Vianga players had an idea that they would be meanly treated, and so they laid their plans accordingly. They called a prominent player in Matadi, and arranged with him to praise the Vianga people in the usual way, and one of the Vianga men would give him 20 francs, which amount he was to return in consideration of a percentage of what the Matadi chief would give. The plan worked well for the Vianga players and their accomplice. Chief Dimbu, seeing 20 francs given, felt compelled to surpass that, and eventually handed over 30 francs.

7. Boela is a circular dance, to the beating of a medium-sized drum. The cloth put on for it is first held under the arm-pits, then the belt is tied tightly round the waist, and the upper part of the cloth is allowed to fall down in folds.

8. Madiumba is a circular dance performed, not to the beating of a drum, but to a marimba.

9. Makuta. The Makuta people got a dance from the Nsundi folk, who live to the east of them, and called it the Nsundi dance, and then the San Salvador people appropriated it, and called it the Makuta dance.

10. Lungondongo is like the Niuta dance, but with a different beat on the drum and a different chorus.

1 I. Ngzinda is like the Etuta, but is danced by the Manyanga people on a cleared space outside the town.

12. Nsanga is danced after a fight, when no one is killed or wounded. There is no formation of rings or 


\section{Customs of the Lower Congo People. 469}

lines, but just a crowd of folk who shout, wave knives, and fire off guns to the sounding beat of a big drum.

13. Nkongo is a hunter's dance, for men only, to the rubbing on the back of the "Nkumbi" or antelope drum. This takes place at the grave of a great hunter. During the rub, rub of the drum the hunters circle round the grave. (See page I8l supra and Plate IX.)

"Ejieta" is the finishing-off movement in a line dance, and means to go round for a turn or two in a circle as 2 wind up.

Other names for dances are "Nzoko," "Manyanga," and "Ngom' a nkanu." The last is used, as its name indicates, at the talking of palavers. At big palavers the orators speak for many hours, and to give them an occasional rest there is a drum beaten, and one or two women dance,-generally only one.

\section{Salutations, Blessings, and CURses.}

When a common man goes into the presence of the king of San Salvador, he kneels on the ground, puts the palms of his hands together, rubs his two little fingers in the dirt, rubs them on his forehead, and claps his hands; this he repeats three times. The king, to show his acceptance of the man and his homage, lays his right hand across the palm of his left, palm to palm, so that the four fingers of the right hand are well above the side of the left hand, and those four fingers he waves to and fro. Should the king not so wave his fingers, the sooner the man gets out of the king's presence, and the greater the distance he puts between the king and himself, the better it will be for his health.

When a common man salutes a chief, he performs the above action twice only, and the chief answers twice in the same way as the king. 


\section{Customs of the Lower Congo People.}

When ordinary people or equals meet, they each clap once only, and relatives also only clap once to each other. Strangers meeting simply clap hands to each other. I have seen the following salutation between acquaintances:-The men have met and deliberately sat down, clapped to each other, crossed their hands so that the right hand of each took the left hand of the other, raised their hands, and finally dropped them loosely. This clapping and touching of hands they repeated solemnly three times, and then began to talk.

In saying good-bye to each other, they pretend to spit on the forehead and hands of the departing one, and on some grass which, after being spat upon, they stick in the hair of the beloved one leaving them. This is to bring good luck and keep away evil spirits.

Men on returning from a journey, or on paying a visit to a town, are greeted with "tukayisi" (welcome), of "tusambwidif" (blessing), and they reply "ingeta" of "inga" (yes, sir). Sometimes the greeting will be "tumonana" (we see each other), when each will clap three times. The women greet with "tumiangana" (prettiness, smartness).

If the king wants to be disrespectful in receiving the homage paid to him, he will simply put out only one hand, and wave the fingers; if he resents the homage, he puts out one foot and moves the toes, which is a sign of coming trouble.

Ordinary villagers meeting during the day say "kiam" bote" (good), and, if it is the morning, they add "olele kwaku?" (did you sleep?) The answer is "ndele kwame" (I did sleep). To sleep is regarded as a sign of good health. When separating during the day, the one going says to the one remaining "sala kiambote" (remain well), and the remaining one says to the one going "wends kiambote" (go well). If it is evening, the farewell greeting is "sala leka kiambote" (remain, and sleep well), and 


\section{Customs of the Lower Congo People. $47 \mathrm{I}$}

the answer is "wenda leka kiambote" (go, and sleep well).

There are two kinds of spitting:-I. "Taulwila nsambu," to spit a blessing or to utter a blessing, to pretend to spit on one as a blessing, as a parent will on a child, etc. When this is done, the one who blesses says "ovwa kiuma kiavwidi muntu, ovwa nsambu yo malau, wata diambu ditonda muntu," (may you possess all that a person should possess, may you have blessings and good luck, and may your words find favour with people). 2. "Taulwila mete," to spit saliva at any one. This is equal to cursing them, and is resented accordingly.

To hit or kick against another's foot in passing, if intentional, is equal to a curse, and will cause a bad quarrel. The man who does it unintentionally must ask forgiveness. The showing of the sole of the foot to a person is considered extremely rude, and to touch another with the sole of the foot is bitterly resented.

Visitors who have been sitting in a town must not brush the dust and dirt off their cloths until they get outside the town, as such an action is regarded as putting a curse on the town.

When a number of people are leaving a town to build another town, or to live somewhere else, the folk remaining wish them good health, good journey, luck, etc., and finish by saying, - Do not any of you return to bewitch us." Those leaving reciprocate the good wishes, and say,- "Do not any of you follow us to bewitch us." When a caravan starts on a trading expedition, the members of it say to those left in the town,- "Good health, and let no one follow us to give us bad luck in trading "; and those left behind say, - "Good journey, and do not any of you return to bewitch us, or carry us to sell to the white trader." The idea behind these requests is that a living person who is a ndoki or witch can visit a place by his "nkwiya" (evil spirit) and take a person away by 


\section{Customs of the Lower Congo People.}

witcheraft. The "nkwiya" can leave its possessor for evil purposes either when he is awake or asleep, and can travel any distance to accomplish its object. The "evuvu" or shell of the person is left behind, while the "nkwiya " takes the journey. The people about will see the "evuvu "before their eyes, but they believe his "nkwiya" has gone on its evil errand. Hence an animal that has killed a man is supposed to be possessed by the "nkwiya" of the ndoki, or it never would have killed the man. The person charged naturally denies that he has an "nkwiya," as no one admits he is a ndoki.

To curse a child or near relative, who is very bad, obstinate, or self-willed, the curser cuts off a piece of his own cloth, and wraps some of his hair in it and burns it, saying,- "You shall never have children, or you shall never become rich." If after a time the child or relative alters his or her conduct, and comes to his parents, say his father, wishing to have the curse removed, the father puts three small heaps of earth on each knee, the child kneels down before him, and the father says,-- "I forgive you, I did not curse you in my heart but with my tongue only, and now from this time have many and strong children and become rich." The child shakes off or blows off each heap of earth from the knee, and the curse is removed. If the father is dead, the child seeks out a namesake of his father with whom he was on friendly terms, and, taking a fowl to him asks him to undo the curse, which he does in the way described above. If a girl wants to marry a man of whom the family does not approve, or refuses to marry one whom they think suitable, they put a curse on her, or, ${ }^{\text {st }}$ they say, "dia e kandu," eat with a curse, or interdict with a curse. The person cursed is "mwan' a kandu" or child of the curse. The most solemn way of promulgating a law, or cursing a town, family, or clan, is that pronounced at the junction of two roads, and confirmed by rubbing the mouth in the dust and striking the knees with one's hands. No 
One will dare to risk the curse that would follow the breaking of a law thus proclaimed, and any family, town, or clan thus cursed would tremble until they either procured its removal or secured the services of the greatest nganga to nullify it.

Evil Eye and Counting.

The "evil eye" is supposed to receive its power from a fetish called "Ezau." The ingredients of the charm are known only to the maker and user, and the possession of such a charm is, of course, a secret, as those known to be in possession of it would soon be accused of witchcraft. The charm used to counteract the evil eye is called "kimbaji-mbaji," and is made by putting various herbs into a univalve shell. When a person feels under the power of the "ezau," he sends for a nganga who owns a good "kimbaji-mbaji" fetish. The nganga kills a fowl as a sacrifice, and puts some of the blood into the shell; he then marks a cross with chalk on the shell and puts it on the ground, surrounding it with eight heaps of gunpowder, which he explodes, and then blows his whistle vigorously. This arouses the charm to work effectively. Sometimes the nganga makes the shell move along the path, to the astonishment of all. The person engaging the nganga is now free from the influence of the evil eye. A woman here with a ground-nut patch who was not ready to gather it has objected to the other women in the village gathering theirs lest they put "ezau" on her patch, and so destroy the possibility of a good harvest. She believed that they had power by using the "ezau" to draw the nuts under ground from her own patch to theirs. The great, wealthy chief Makitu, now dead, was supposed to possess an "ezau" by which he put a ban on other folk's goods and thus became rich by their misfortunes.

It is considered very unlucky for a person to count her children one, two, three, and so on, for evil spirits will hear 


\section{Customs of the Lower Congo People.}

and take some of them away by death. The people them. selves do not like to be counted. They fear that counting will draw the attention of the evil spirits, and that they will die. A short time ago the Congo State officials, desiring to number the people for taxing purposes, sent an officer with soldiers to count them. The natives would have resisted him, but he had too many soldiers with him.

\section{OMENS.}

A cock crowing at the wrong hour is killed because it is an evil omen. From 8 p.m. to I a.m. are regarded as illomened hours for crowing.

If the "ntoyo" or blue plantain-eater chirps near a man's house early in the morning, it is a sign of death.

"Ta esakuba," to strike the foot against anything. If a man does this in the road it is regarded as a bad omen. If it happens, men on a journey will return to the nearest town and start again a few hours later, or next day. Some turn round and strike the object again with the foot to remove of undo the evil effects of the first striking. A man striking his foot on the way to a hunt will turn back, for he knows he will have no success. Men going to fight another town have to jump over the "medicine saucepan" of the ngangd, and should one strike his foot against it he is forcibly restrained from going to the fight. To step over a person's body or legs will cause ill-luck to that person, and is most carefully avoided by all passing between men during a palaver. The man passing will shuffle his feet along the ground and thus avoid lifting them, so as not to be charged with bringing bad luck to any one.

\section{CanNibalisa.}

Some natives think that this practice was common among the people, as there are traces of it yet to be found in the fact that men will drink the blood, and eat the livers, of 
those they have killed in a fight. This is not a common custom, but it is sometimes done. Over twenty-five years ago I knew a chief near San Salvador of whom it was generally reported that he had eaten the liver of a Portuguese soldier he had killed in battle when the Portuguese fought on behalf of Dom Pedro V. and reinstated him as King of San Salvador some twenty years previously.

\section{Beliefs about Fire.}

Fire came first from above by lightning striking a tree and setting it on fire. People will not now go near a tree that has been struck by lightning, and, if the tree is near the road, everyone who passes it will tie a single bow in the grass every time they pass along that road. A mother will put the grass into the hand of her child while she ties the bow. This is to avert some indefinable evil that will fall on them should they omit the observance of this rite. When palm-trees and "nsafu" trees are struck by lightning, no one will again eat their fruits, and the same applies to any fruit-tree. A person killed by lightning is buried at the cross roads, as he (or she) is supposed to have been slain by the fetish "Nzaji," "Who controls the lightning. All those who are killed by "Nzaji" are treated in this way, e.g. a man who bleeds from the mouth and nose is said to be killed by "Nzaji," and his corpse is put into a grave dug by the road-side, and two stakes are driven into him, -one through the chest and the other through the stomach,-and the body is left uncovered. The diseases, and death by lightning, inflicted by "Nzaji" are especially for stealing, but not solely for this crime; and a person who dies by lightning or by a "Nzaji" sickness is regarded as a very bad person, and may not be buried with respectable folk. It may be that the tree struck by lightning is supposed to have done samething worthy of the "Nzaji"'s punjshment, and hence those who can avoid the tree, and those who have to 


\section{Customs of the Lower Congo People.}

go near it tie a single bow to avert a like misfortune from themselves. There is another statement respecting the origin of fire, according to which fire was first made by wood friction, and then by flint and steel. There is $a$ native legend that once there was no fire on the earth, and a man sent a jackal, (which at that time was tame and lived in the villages), to where the sun sets to bring some fire from it, but the jackal found so many good things there that he never again returned to the abode of man.

Salt must never be thrown on the fire, or it will prevent the rain from ever coming again. Neither may a person spit in the fire, or he will suffer from a sickness in which "the blood will become thin, the hair turn reddish, and dropsy of the stomach will appear."

\section{Beliefs about Stars.}

"Nienie" or shooting stars are believed to be "matom" bola" (ghosts or spirits) travelling or playing, and anyone seeing them will rush into a house from fear of one of them falling on him and entering him. Mothers will not allow their children outside the house when there are many" shooting stars to be seen, lest one should enter one of them. "Matombola" comes from " tomba," to ascend. It is thought that the "matombola" are spirits that have ascended from their graves. Mouse-holes are regarded as the exits of these spirits. Having ascended from their graves, they are now looking out for a body to enter, and upon entering one they" become "nkwiya" (the evil spirit in a man that is the source of all witcheraft). There is the "mwanda" or spirit of a man which is buried with his corpse, and also the "etom" bola" or ghost which enters a person and becomes a "nkwiya" or evil spirit, and the person who has the nkwiy" becomes a ndoki, or a witch who causes sickness and death. Now no one wants to be a witch, so they get out of the way" of shooting stars. The "matombola" are not confined to 
shooting stars, but can wander in the forests and enter folk by other means. They come out of the grave to steal fowls, etc., and cause much mischief.

The three stars of Orion's belt are called "mbwa yo naiji yo nkongwa-mbwa," (the dog, the palm-rat, and the hunter). Venus is named "Nkaz' a Ngonde," (wife of the moon), and the Pleiades "Ndunda-lunda zalunda mula" (the caretakers who guard the rain). It is thought that the rain comes from the Pleiades, and if, at the beginning of the rainy season, this constellation is clearly seen, the natives expect a good rainy season.

\section{WATER SPIRITS.}

"Ximbi" are water spirits that keep the water good and fit to drink. They are said, by those who pretend that they have seen them, to have short, little bodies, and are white. The ximbi are responsible for landslips and chasms. They travel in the whirlwind and great storms. When a white person dies at Wathen Station, the natives say that the ximbi which inhabit the neighbouring streams do not like white people. Snakes are to be found frequently among the stones along the banks of rivers and streams, and therefore they are regarded as under the protection of the ximbi, and are sometimes said to be incarnations of ximbi. These ximbi are regarded also much as we regard fairies, and are, according to some of the stories, possessed of similar powers.

When a pregnant woman dreams of water, or snakes, or ximbi, she believes that her child is an incarnation of a ximbi. Directly the child is born, a cloth is tied round it to hide its sex, and no one is allowed to know its sex except the nganga. A short time after the birth, the "Danga arrives and starts the dance called "Ekinu," (see "Dances" (I) above), which is danced all night and is accompanied by much eating and drinking. A bower of palm fronds is made, and the father, mother, and child sit 


\section{Customs of the Lower Congo People.}

under it. All the plates, dishes, and small saucepans used during the confinement are brought out of the house, and put near the booth. At dawn a plate of palm wine is pro" cured, and the "ngang' a nkisi" dips some "lemba-lemba" leaves in the wine and sprinkles the baby, the mother, and the father, after which he asks the crowd three times if they know the child's name. They answer,- "No, we don't know the name." The nganga shouts out,-- "It is Lombo." The people then make a noise by clapping their mouths. The folk, on hearing the name Lombo, would know that the child was a girl, for, if a boy, it would have been called Etoko, and they also know from the name given that the mother has dreamed of ximbi, or water, or snakes. The nganga would receive as his fee one fowl, 15 strings of blue beads, and all the utensils that had been put outside the house.

When the child grows up, it receives presents from its relatives on account of its spirit nature. The ximbi are supposed to endow one thus born with various powers and fairy gifts, and hence presents are given to "Lombo" and "Etoko" children by relatives and neighbours, to gain the goodwill of these incarnations or favourites of the ximbl. As stated above, snakes are either under the special protection of the ximbi or are incarnations of them, and, on account of this connection, snakes are not killed or hurt in a house where these spirit children have been born, and neither "Lombo" nor "Etoko" children are allowed to kill snakes, lest they should kill one of their kith and kitn They do not drive them from their houses, and snakes, apparently conscious of their immunity, are most frequently found in the houses of those men and women called "Etoko" and "Lombo." Again, the most vulnerable part of a snake is its head, and people must not strike these spirit children on the head. There is an indefinable but clear connection in the native mind between the ximbi, snake, and the spirit children "Lombo" and "Etoko."

These water-spirit children can impart not only good 


\section{Customs of the Lower Congo People.}

fortune, but also inflict misfortune. The presents referred to above are to bring the one and avert the other from the givers, and the whole idea of the "christening" ceremony is to make the spirit child amenable to the ordinary rules of life. "Lemba-lemba" leaves are only used by the nganga when something uncanny is to be counteracted in the person subject to his rites, as in the case of a madman, homicide, etc.

The natives believe even now that we white folk do not weave our cloth, but that the ximbi of the sea weave all the cloth beneath the waves, and that we have found an opening leading to their oceanic factory and, whenever we want cloth, we simply ring a bell at the hole (ntumpa), and the Kimbi, without showing themselves, push up the end of a piece of cloth and we pull it yard by yard and length by length until we have all we want, and then we cut and fold it into pieces, and bind it into bales. They also believe that the cloth-weaving ximbi have only one eye, and that the power of sight of the two eyes is concentrated in the one eye, which enables them to weave such fine, close cloth. $W_{e}$ are supposed to pay the ximbi by taking to them the spirits of the natives we have collected or bewitched to death, to become the slaves of the ximbi. The natives, believing that the cloth costs us little or nothing, are never satisfed with the presents travellers make them in cloth, and hence arise all the stories of native greed. The belief that we bewitch the natives so as to send their spirits to become the slaves of the ximbi causes their opposition to travellers and others who live in or pass through their country for no ostensible reason. The native understands the reason for a trader living here, but not for the presence of travellers, explorers, and missionaries.

"Kimenga" OR SACRIFICR.

I do not think that there is any idea of worship in "kimenga," or sacrifice, and no prayers are offered when the 


\section{Customs of the Lower Congo People.}

kimenga is made. The root idea is that in some way the kimenga renews the power in a fetish image or bundle of charms. It refreshes the fetish, and enables it to perform more effectually its office of protector of its owner, punisher of his enemies, and imparter of good fortune. A fowl of goat is killed, and its blood is poured over the image or charm, for these kimenga are made not only to images but also to bundles of charms. Sometimes the toe of a fowl is cut and the blood is allowed to fall on the fetish, and even the toe of a frog is cut and used as a kimenga. If the fetish is to be kept up to its full power, the sacrifice should be made regularly, e.g. at every new moon, or on certain market days, and the larger the favours expected the more costly must be the sacrifice. The fetish receiving only the drippings from a fowl's or a frog's toe cannot be expected to confer large favours. At the same time some fetishes can only impart small favours, and consequently it would be waste to give them a large kimenga, such as a large fowl or goat. Other fetishes, owned by wealthy men, give great good fortune, and their wealthy owners can afford to offer goats and fowls. The flesh of a sacrifice must not be sold, but eaten by the man who offers it and the members of his clan. Sunset is the usual time for offering the kimenga, and the person who kills the sacrifice turns his face towards the sun. A pig is never offered as a sacrifice, although it is more plentiful than the goat. My informant cannot guess at any reason for this restriction. I think it is probably reckoned unclean, as the planter of certain seeds is not allowed to eat it. (See also the description of a hunting sacrifice on p. 181 supra.)

JOIN H. WEEKS. 